\title{
Health Care Professionals' Attitudes about Using Computer
}

\author{
Ayşegül Koç*1, Mahmut Kılıç², Dilek Öztaş ${ }^{3}$, Erdal Ceylan $^{4}$ and Kamile Sılay ${ }^{5}$ \\ ${ }^{1}$ Department of Nurse, Faculty of Health Sciences, Ankara Ylldırım Beyazıt University, Turkey \\ ${ }^{2}$ High school of Health, Bozok University, Turkey \\ ${ }^{3}$ Department of Public Health, Medical School, Ankara Yıldırım Beyazıt University, Turkey \\ ${ }^{4}$ Faculty of Health Sciences, Ankara Ylldirım Beyazıt University, Turkey
}

${ }^{5}$ Department of Medicine, Medical School, Ankara Ylldırım Beyazıt University, Turkey

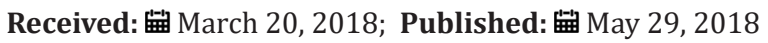

*Corresponding author: Ayşegül Koç, Department of Nurse, Faculty of Health Sciences, Ankara Ylldırım Beyazıt University, Turkey

\section{Abstract}

Aim: This cross sectional study was conducted among health care professionals working in special and state health institutions in Yozgat to determine health care professionals' attitudes about using computer in health care institutions.

Method: Sampling was done by random sampling method with 1/4 rate and 197 samples were taken for the study. Data was collected using a questionnaire prepared in accordance with the literature by the researchers. Statistical analysis of the data was performed by using Reliability analysis, chi-square test and binary logistic regression analysis.

Result: Half of the research group was working in second level public health institutions and 22.3\% in private health institutions. Seventy one percent of the participants stated that they use computers at work. Seventy percent of the respondents thought that using computers would affect informatics positively and $77.2 \%$ think that it would affect the health care/medication positively. Employees in the public sector and long-term computer users were more likely to think that using computers in health facilities is important. There were no significant differences according to the health professionals' use of computers, sex, age, education, occupation and computer use at work.

Conclusion: The vast majority of health personnel thought that using computers in health facilities is important.

Keywords: Attitudes of using computer; Health care professionals; Health care facilities

\section{Introduction}

In recent years, there have been significant changes and developments in the health professions, especially nursing, with the development of technology [1,2]. The use of computers in nursing has increased in the 1970 s due to the need for nurses to document information and services they provide [3]. In these years, computers have been used effectively in diagnosing, treating, planning, implementing, evaluating and keeping records of healthy/sick person's problems [2,3]. Computerized and computer controlled systems, uncontemporary medicine, provide extraordinary dimensions of diagnosis and treatment, provide great convenience, accelerate healthcare delivery, reduce costs, and ensure that the relevant patient data is available in a short period of time. It also allows the interpretation of many complicated and very close events in a fast, secure and accurate way [1]. Health services become increasingly complex and become connected to computers day after day [2]. The usage of computers has become indispensable when information and technology begin to integrate with health services [4]. Every year, the amount of medical data 
belonging to the disease has been increasing at a great rate. It is becoming increasingly difficult to regain access to these data. As a result, there is a great need and demand for the use of computer and information technology [2].

When studies about usage of computers in health services of health workers are examined, according to Eriş's study (2016), the usage of electronic medical records of nurses, quality and user satisfaction dimensions were found to be moderate [5]. According to findings in Köse's research, it was found that $22 \%$ of the nurses could not use the computer and $10 \%$ had never used the computer before. In another study conducted by Orun and Kula's (2012), it was stated that $93.6 \%$ of the personnel of the health personnel knew how to use the computers [6]. Similar results were obtained by Değirmen and colleagues. Their study showed that nearly all the healthcare staff working in surgical clinics knew how to use computer and $82.4 \%$ of them use computers for recording data [7]. Erdemir and colleagues (2005) indicated that usage of computer in the healthcare care environment was positive in terms of the benefits of care giving, occupation, service documentation and knowledge accumulation [8]. In health services, which are increasingly prevalent in information technology, the usage of computers by health professionals is important in terms of providing effective, efficient and good quality services. In health care delivery, nurses are unaware of the growing effects of computer technology or are not actively involved in computer use. In this context, the aim of the research was to determine health care professional's attitudes about using computer effectively in health care facilities.

\section{Materials and Method}

This research is a descriptive study. A total of $\mathrm{N}=850$ health professionals constitute the universe of research, including 210 nurses working in private and public health units in the province of Yozgat. Sampling was chosen by random sampling method with $1 / 4$ rate and $n=197$ samples were taken for the study. Data was collected by using a questionnaire prepared in accordance with the literature by the researchers. Questionnaires were filled in by the respondents. Verbal approvals were obtained by explaining the aim of research to the respondents. Thirteen people refused to participate in the survey and 3 people were not taken into account for the lack of data. Approval of the institutional permission and approval of the ethics committee was made in order to conduct the research.

Table 1: Percent distribution of answers given by healthcare staff to questions about attitudes towards using computers in health care facilities.

\begin{tabular}{|c|c|c|c|c|c|}
\hline Attitude Subjects About Using Computers in Health Care $(n=197)$ & $\begin{array}{l}\text { Absolutely } \\
\text { I agree }\end{array}$ & I agree & -- & $\begin{array}{c}\text { Partly agree I do } \\
\text { not participate / } \\
\text { I definitely do not } \\
\text { participate }\end{array}$ & $\begin{array}{l}\text { Average } \\
\text { (SD) }\end{array}$ \\
\hline $\begin{array}{l}\text { 1. The package program for the registration of patients in health facilities } \\
\text { should be used. }\end{array}$ & 68.0 & 23.9 & 7,1 & 1,0 & $4,6(0,7)$ \\
\hline 2. Computers used in health institutions should be open to internet usage. & 59,4 & 19,8 & 15,7 & 5,1 & $4,3(1,0)$ \\
\hline 3. The use of computers in health facilities prevents data loss. & 50,8 & 22,8 & 10,7 & 15,7 & $4,0(1,2)$ \\
\hline
\end{tabular}

Thirteen questions were prepared to measure the nurses' considerations regarding the use of computers in health care facilities. The questions were Likert type: strongly agree $=5$, agree $=4$, partly agree $=3$, disagree $=2$, strongly disagree $=1$. The scores of 13 attitude questions were collected and the smallest score was 13 , the largest score was 65 and the range was 52 . The reliability of the attitude questions (standardized Cronbach's Alpha value 0.866) was sufficient. As a result of the factor analysis, 13 questions were collected in two groups. These two groups of questions were named as information attitude and treatment/care attitude.

Total attitude questions, I agree: $4 \times 13$ questions $=52$ points and above; I agree with the information questions: $4 \times 7$ questions $=28$ points and above; I agree with the treatment/care: $4 \times 6$ questions $=24$ points and those who received it were rated as having positive attitude. Percentage of positive attitude and attitude score were calculated according to gender, education status, age groups, occupation, computer use at work, duration of computer use, and health facility. The data were evaluated by SPSS statistical program. In the analysis of the data, chi-square test, t-test, ANOVA and binary logistic regression (LR) analysis were used. Statistically significant independent variables $(\mathrm{p}<0.20)$ were included in the Forward LR (FLR) analysis. The results of the variables that are important in the

\section{Results}

Sixty nine percent of the participants were women, $34.5 \%$ were high school graduates, $43.7 \%$ were nurses, $10.1 \pm 8.1$ years in occupational working year and $31.6 \pm 8.7$ years old in average. Half of the research group was working in the secondary public health institutions and $22.3 \%$ were working in the private health institutions. Seventy one percent of the health care professionals stated that they use computers at work.

The lowest average scores (4.0) from the attitude questions were the third and 12th questions (respectively; "computer use in health facilities prevents loss of data" and "electronic mail, chat etc. facilitate communication with patients and other health professionals"), the highest (4.6) were the first and the 10th questions ("Package program should be used for the registration of patients in health institutions" and "Access to the patient's previous data increases quality of the planned intervention, treatment and care") (Table 1). analysis are tabulated. 


\begin{tabular}{|c|c|c|c|c|c|}
\hline $\begin{array}{l}\text { 6. Recorded data are; provides a resource for evaluating the performance of } \\
\text { health personnel. }\end{array}$ & 44,7 & 40,6 & 12,7 & 2,0 & $4,3(0,8)$ \\
\hline 11. Provides data sharing between health institutions. & 55,3 & 28,9 & 12,7 & 3,0 & $4,3(0,9)$ \\
\hline $\begin{array}{l}\text { 12. Electronic mail, chat etc. facilitates communication with patients and other } \\
\text { health professionals. }\end{array}$ & 42,6 & 25,9 & 20,3 & 11,2 & $4,0(1,1)$ \\
\hline 13. It makes it easier for patients to access their own information. & 52,3 & 31,5 & 9,6 & 6,6 & $4,3(0,9)$ \\
\hline 4. It ensures that treatment and care are patient-specific. & 49,7 & 35,0 & 10,7 & 4,6 & $4,3(0,9)$ \\
\hline $\begin{array}{l}\text { 5. The use of computers in health facilities contributes to the overall care of } \\
\text { the patient. }\end{array}$ & 44,2 & 33,5 & 15,2 & 7,1 & $4,1(1,0)$ \\
\hline 7. The infrastructure is in place to develop patient care standards. & 42,1 & 41,1 & 13,7 & 3,0 & $4,2(0,8)$ \\
\hline $\begin{array}{l}\text { 8. The intervention made by the patient makes it easier to share the treatment } \\
\text { and care within the health team members. }\end{array}$ & 53,8 & 36,5 & 6,6 & 3,0 & $4,4(0,8)$ \\
\hline $\begin{array}{c}\text { 9. The patient's intervention ensures that treatment and care are more } \\
\text { reliable. }\end{array}$ & 53,3 & 32,0 & 11,7 & 3,0 & $4,3(0,8)$ \\
\hline $\begin{array}{l}\text { 10. Achieving the patient's previous data increases the quality of the } \\
\text { intervention, treatment and care planned for the patient. }\end{array}$ & 65,0 & 28,9 & 4,6 & 1,5 & $4,6(0,6)$ \\
\hline
\end{tabular}

Seventy percent of the health personnel had positive attitude towards the use of computers in health institutions. Positive attitude was found to be statistically significant in relation to the age of the health care personnel, the institution to be employed and the duration of computer use, whereas sex, educational status, occupation and computer use at work were not significant. The attitude score average was found to be different according to the age groups and the institution they worked with, while the other

Table 2: Percent distribution of positive attitudes towards using computers in health facilities according to various characteristics of health personnel.

\begin{tabular}{|c|c|c|c|c|c|}
\hline Various features & n (\%) & Information attituden (\%) & Treatment attituden (\%) & Total attitude n (\%) & $\begin{array}{c}\text { Total score average } \\
\text { X (SS) }\end{array}$ \\
\hline \multicolumn{6}{|l|}{ Sex } \\
\hline Male & $61(31,0)$ & $45(73,8)$ & $46(75,5)$ & $46(75,4)$ & $55,8(7,3)$ \\
\hline Female & $136(69,0)$ & $94(69,1)$ & $106(77,9)$ & $93(68,4)$ & $55,7(7,1)$ \\
\hline Education status & $\mathrm{X}^{2} ; \mathrm{p}$ & 0,$4 ; 0,508$ & 0,$2 ; 0,696$ & 1,$0 ; 0.317$ & $\mathrm{t}=0,1 ; \mathrm{p}=0,923$ \\
\hline High school & $68(34,5)$ & $49(72,1)$ & $48(76,6)$ & $44(64,7)$ & $54,4(7,5)$ \\
\hline Associate Degree & $82(41,6)$ & $61(74,4)$ & $67(81,7)$ & $63(76,8)$ & $56,7(6,2)$ \\
\hline License and above & $47(23,9)$ & $29(61,7)$ & $37(78,4)$ & $32(68,1)$ & $56,1(7,8)$ \\
\hline Occupation & $X^{2} ; p$ & 2,$4 ; 0,297$ & 2,$7 ; 0,260$ & 2,$8 ; 0.245$ & $\mathrm{~F}=1,9 ; \mathrm{p}=0,145$ \\
\hline Physicians & $23(11,7)$ & $18(78,3)$ & $19(82,6)$ & $19(82,6)$ & $58,6(6,3)$ \\
\hline Nurses & $86(43,7)$ & $58(67,4)$ & $70(81,4)$ & $59(68,6)$ & $55,8(7,0)$ \\
\hline Other health staff & $88(44,7)$ & $63(71,6)$ & $63(71,6)$ & $61(69,3)$ & $54,9(7,3)$ \\
\hline Age groups & $\mathrm{X}^{2} ; \mathrm{p}$ & 1,$1 ; 0,576$ & 2,$8 ; 0,245$ & 1,$8 ; 0,400$ & $F=2,5 ; p=0,84$ \\
\hline $18-24$ & $52(26,4)$ & $23(63,5)$ & $30(57,7)$ & $30(57,7)$ & $53,3(7,5)$ \\
\hline $25-34$ & $77(39,1)$ & $53(68,8)$ & $67(87,0)$ & $54(70,1)$ & $56,4(6,7)$ \\
\hline$\geq 35$ & $68(34,5)$ & $53(77,9)$ & $55(80,9)$ & $55(80,9)$ & $56,9(6,9)$ \\
\hline Working institution & $X^{2} ; p$ & 3,$2 ; 0,206$ & 16,$0 ;<0,001$ & 7,$6 ; 0,022$ & $\mathrm{~F}=4,5 ; \mathrm{p}=0,012$ \\
\hline State hospital / ODHC & $105(53,3)$ & $76(72,4)$ & $87(82,9)$ & $80(76,2)$ & $56,3(6,8)$ \\
\hline $\begin{array}{l}\text { Private hospital/ } \\
\text { medical center }\end{array}$ & $44(22,3)$ & $26(59,1)$ & $27(61,4)$ & $23(52,3)$ & $52,7(7,6)$ \\
\hline Primary health care & $48(24,4)$ & $37(77,1)$ & $38(79,2)$ & $36(75,0)$ & $57,4(6,6)$ \\
\hline $\begin{array}{c}\text { Using a computer at } \\
\text { work }\end{array}$ & $X^{2} ; p$ & 3,$9 ; 0,140$ & 8,$3 ; 0,016$ & 9,$1 ; 0,010$ & $F=6,1 ; p=0,003$ \\
\hline Don't use & $57(28,9)$ & $36(63,2)$ & $40(70,2)$ & $36(63,2)$ & $55,2(7,4)$ \\
\hline
\end{tabular}




\begin{tabular}{|c|c|c|c|c|c|}
\hline Use & $140(71.1)$ & $103(73,6)$ & $112(80,0)$ & $103(73,6)$ & $56,0(7,0)$ \\
\hline Computer usage time & $\mathrm{X}^{2} ; \mathrm{p}$ & 2,$1 ; 0,146$ & 2,$2 ; 0,136$ & 2,$1 ; 0,146$ & $\mathrm{t}=0,7 ; \mathrm{p}=0,461$ \\
\hline Don't use & $15(7,8)$ & $9(60,0)$ & $8(53,3)$ & $49(46,7)$ & $52,9(7,0)$ \\
\hline Use (1-4 year) & $70(35,5)$ & $43(61,4)$ & $66(83,5)$ & $64(81,0)$ & $54,7(7,3)$ \\
\hline Use (5-9 year) & $79(40,1)$ & $62(78,5)$ & $29(87,9)$ & $26(78,8)$ & $57,0(7,0)$ \\
\hline Use ( $\geq 10$ year) & $33(16,8)$ & $25(75,8)$ & 10,$8 ; 0,013$ & 13,$1 ; 0,004$ & $\mathrm{~F}=2,2 ; \mathrm{p}=0,087$ \\
\hline & $\mathrm{X}^{2} ; \mathrm{p}$ & 6,$4 ; 0,092$ & $152(77,2)$ & $139(70,6)$ & $55,8(7,1)$ \\
\hline
\end{tabular}

When the variables with significance level $\mathrm{p}<0,20$ were taken into the FLR analysis, the information attitude was not significant compared to any variables. But total positive attitude of those who worked at "State Hospital/Dental Health Center" was 2.7 times higher than those who worked at "Private Hospital/Private
Medicine Center". There was no significant relationship between computer use and attitude at age and place of work (Table 3). The vast majority of health personnel, especially those in the public sector and those who use long-term computers, thought that it is important to use computers in health facilities.

Table 3: Multiple analysis of FLR variables of health staff which may have influence on computer usage attitudes in health institutions.

\begin{tabular}{|c|c|c|c|c|c|c|}
\hline \multirow{2}{*}{$\begin{array}{l}\text { Variables Total } \\
\text { attitude }\end{array}$} & \multirow{2}{*}{$\beta$} & \multirow{2}{*}{ Wald $X^{2}$} & \multirow{2}{*}{$\mathbf{P}$} & \multirow{2}{*}{ Odds ratio } & \multicolumn{2}{|c|}{ 95\% Confidence Interval } \\
\hline & & & & & Bottom & Top \\
\hline \multicolumn{7}{|c|}{ Health organization } \\
\hline $\begin{array}{c}\text { State hospital / } \\
\text { ODHC }\end{array}$ & Ref. & 7,351 & 0,025 & 1 & & \\
\hline $\begin{array}{l}\text { Private hospital / } \\
\text { medical center }\end{array}$ & $-0,984$ & 6,520 & 0,011 & 0,374 & 0,176 & 0,796 \\
\hline $\begin{array}{l}\text { Primary health } \\
\text { care }\end{array}$ & $-0,010$ & 0,001 & 0,980 & 0,990 & 0,444 & 2,206 \\
\hline $\begin{array}{l}\text { Computer usage } \\
\text { time }\end{array}$ & 0,095 & 3,920 & 0,048 & 1,100 & 1,001 & 1,208 \\
\hline Constant & 0,648 & 3,688 & 0,055 & 1,911 & & \\
\hline \multicolumn{7}{|c|}{ Treatment attitude } \\
\hline \multicolumn{7}{|c|}{ Health organization } \\
\hline $\begin{array}{l}\text { State hospital / } \\
\text { ODHC }\end{array}$ & Ref. & 6,345 & 0,042 & 1 & & \\
\hline $\begin{array}{l}\text { Private hospital / } \\
\text { medical center }\end{array}$ & $-1,009$ & 6,028 & 0,014 & 0,364 & 0,163 & 0,816 \\
\hline $\begin{array}{c}\text { Primary health } \\
\text { care }\end{array}$ & $-0,182$ & 0,168 & 0,682 & 0,833 & 0,348 & 1,993 \\
\hline $\begin{array}{l}\text { Computer usage } \\
\text { time }\end{array}$ & 0,111 & 4,228 & 0,040 & 1,117 & 1,005 & 1,242 \\
\hline Constant & 0,990 & 7,159 & 0,007 & 2,690 & & \\
\hline
\end{tabular}

Independent variables: Age and duration of computer use (continuous variable), use of computer at work and institution (categorical variable).

\section{Discussion}

Sixty nine percent of the participants were women, $34.5 \%$ were high school graduates, $43.7 \%$ were nurses, $10.1 \pm 8.1$ years in occupational working year and $31.6 \pm 8.7$ years old in average. Half of the research group was working in the secondary public health institutions and $22.3 \%$ is working in the private health institutions. Seventy one percent of the health care professionals stated that they use computers at work (Table 2). Similar to our findings, according to Çakırlar's study (2016), 90.9\% of the respondent nurses stated that they use computers in clinics [9]. In contrast, according to Odiwuor and collegues' study (2015), only $27.6 \%$ of participating health professionals stated that they use computers in their workplace. In the same study, only $9.7 \%$ of the participants reported that they have access to medical information via using internet [10]. Another study by Alwan and collegues showed that only $29.5 \%$ of the respondents had good habits of using computers in health care facilities [11]. According to Çınaroğlu and Avcı's study (2015), only $41 \%$ of the nurses stated that they use computers for electronic health records longer than 4 years [12]. In our study, the rate of computer usage in health care facilities was found to be higher than other studies in the literature. When we consider that 
using computer in health care facilities provides important benefits such as easy access to patient records, increased quality of patient care and proper storage of patient information, the result we found is becoming more significant.

In our study, $70.6 \%$ of the health personnel were found to have a positive attitude towards using computers in health care facilities. In the study conducted by Adane and his colleagues, it was determined that nurses generally have positive attitudes towards using computers in health care institutions and respondents' computer literacy was good as well [13]. In another study conducted by Sukums and collegues with 108 health care professionals, it was found that most of the participants were found to have positive attitudes towards computer usage in health care institutions they work with [14]. Our findings are parallel to the literature. These results are thought to be caused by awareness of the health care professionals about importance of computer and other information technologies in order to increase quality of care and treatment, to keep patient records in electronic environment, to reach information fast and cheaply and to increase productivity.

According to our findings, those statements with the highest attitude averages were "Package program should be used for the registration of patients in health institutions" and "Reaching the patient's previous data increases the quality of the intervention, treatment and care planned for the patient". Similar to our findings, according to Çalık and collegues' research, 84\% of the team members who participated in the study expressed that the package program must be used in hospitals. Also, $77.3 \%$ of them stated that they would reach the previous data of the patient and increase the quality of the planned intervention by using the computers [15]. According to both of the studies of Tsoromokos [16] and Adeleke [17], nearly all of the respondent health care professionals think that use of computers in health care facilities increase the quality of care and treatment.

In our study, the attitude score average was found to be different according to age groups and institution to work, while other demographic variables were not significant. Similar to our study, Softa and colleagues determined that the mean scores of attitudes towards computer usage in health care facilities showed statistically significant difference according to age and the type of institution studied (government institution-private institution) [1]. Similarly, according to Alwan and collegues' study, there was a statistically significant relation between age and work area and computer usage habits [11]. In addition, no significant relationship was found between gender, study year and education and computer use attitude in Tsoromokos and collegues' research [16]. Orun and Kula determined that there was a decrease in the level of using informatics among health care professionals as age progressed [6]. In parallel with these findings, Çelik and Tetik (2016) found that the health care professionals in the age between 26 -30 have higher use of information technology skills than those working at age 41 and above [18]. Because the younger ones are more integrated with technology, following the developing technology more easily and being able to adapt to the information technologies more easily, their attitude average scores may be found higher. The computer and technology services provided by the working organizations may be different. Technology in government institutions is not the same as technology in private institutions. Because private institutions are more intertwined with technology, the attitude point average of health care personnel in private institutions may be found higher.

Participants' Information Technology attitude was found to be different according to the duration of computer use (Table 2). Koivunen and colleagues have also found that nurses with longer computer experience had more motivation to use computers than those with less experience [19]. Çelik and Tetik also noted that younger healthcare professionals and those who had longer duration of computer usage had higher skills of Information Technologies usage [18]. These results showed that healthcare professionals who were able to use computers at a good level and those who used computers with longer durations were more likely to define positive statements about use of electronic health records.

\section{Conclusion}

It has been determined that most of the health care professionals use computers at work and they have positive attitudes towards using computers in health care facilities. Positive attitude was statistically in relation with age of the health care professionals, the institution they were working with and the duration of computer usage, whereas sex, education, occupation and computer usage at work were not statistically in relation with positive attitude. In this context, in order to increase the usage of computers in health care applications, nursing students should be prepared to using computer technology in order to start from the education-training period. For this purpose, as a first step, it is very important to make the necessary arrangements for determining the opinions and thoughts about the use of computers in health care professionals' education and practices in the direction of the obtained data.

\section{Reference}

1. Softa HK, Akduran F, Akyazı E (2014) Evaluation of nurses' attitudes towards computer usage. Gümüşhane University Journal of Health Sciences 3(3): 845-858.

2. Köse A (2012) An empirical study on the determination of computer usage situations of nurses-Trabzon case. Journal of Information Technologies 5(1): 37-43.

3. Fidancıoğlu H, Beydağ KD, Özer FG, Kızılkaya M (2009) Opinions of school of health students on internet usage. Maltepe University Nursing Science and Art Journal 2(1): 3-9.

4. Çalıbaşı G, Kaçar KG, Doğan Y, Tarı M, Sarı B, Tonç S (2014) Biostatistics and bioinformatics program usage frequency and awareness in İnciraltı Campus. Journal of Dokuz Eylül University Faculty of Medicine 28(2): 45-50.

5. Eriş H (2016) Nurses' opinions about electronic medical records used in hospitals: Şanlıurfa example. Health Care Acad J 3(3): 93-99. 
6. Orun E, Kula S (2012) Measuring the level of knowledge of health care workers working in various stages: university hospital and health care practice. Journal of Information Technologies 5(1): 29-35.

7. Değirmen N, Yeter K, Calık E (2007) Determination of computer usage situations of health personnel in surgical clinics. In: Verbal Declaration. Proceedings of the IX. Academic Informatics Conference, Kütahya.

8. Erdemir F, Hanoğlu Z, Akman A (2005) The opinions of nurses about computer and internet usage status and value of computer usage in nursing. In: Verbal Declaration. Proceedings of the II. National Medical Informatics Congress, Antalya.

9. Çakırlar A (2016) Evaluation of information and attitudes of nurses in electronic health record and informatics applications [dissertation]. Istanbul Science University, Istanbul.

10. Odiwuor CW, Onyuka JHO, Muhoho F, Muchiri J, Yegon C, et al. (2015) Utilization of information communication technology (ICT) among healthcare providers in Gatundu north district of Kiambu County, Kenya. International Journal of Applied Research 1(11): 1025-1029.

11. Alwan K, Awoke T, Tilahun B (2015) Knowledge and utilization of computers among health professionals in a developing country: acrosssectional study. JMIR Human Factors 2(1): 4.

12. Çınaroğlu S, Avcı K (2015) Comparison of asessments of medical and surgical nurses about usage of electronic health records. TAF Preventive Medicine Bulletin 14(3): 257-264.
13. Adane M, Lessa L, Shiferaw S Knowledge, attitude and utilization of information communication technologies (ICTs) in an Ethiopian Medical Teaching Hospital. p. 1-10.

14. Sukums F, Mensah N, Mpembeni R, Kaltschmidt J, Haefeli WE, Blank A (2014) Healthworkers' knowledge of and attitudes towards computer applications in rural African health facilities. Global Health Action $7(10): 24534$

15. Calık E, Yeter K, Değirmen N (2017) An Investigation of the multispliner attitudes of team members about computer usage in the creation of patient data in surgical clinics.

16. Tsoromokos D, Harami E, Dermatis Z, Lazakidou A (2015) Knowledge and attitudes from Healthcare Professionals toward to the Computers. International Journal Of Health Research and Innovation 3(1): 29-47.

17. Adeleke İT, Salami AA, Achinbee M, Anamah TC, Zakari İB, Wasagi MH (2015) ICT knowledge, utilization and perception among healthcare providers at National HospitalAbuja, Nigeria. American Journal of Health Research 3(1-1): 47-53.

18. Çelik L, Tetik M (2016) Investigation of information technologies usage skills of Afyonkarahisar oral and dental health center staff. Journal of Strategic Research in SocialScience 2(1): 45-60.

19. Koivunen M, Valimaki M, Koskinen A, Staggers N, Katajisto J (2008) The impact of individual factors on healthcare staff's computer use in psychiatric hospitals. Journal of Clinical Nursing 18, 1141-1150.

\section{(c) (P) This work is licensed under Creative}

To Submit Your Article Click Here: Submit Article

DOI: $10.32474 /$ LOJNHC.2018.01.000111

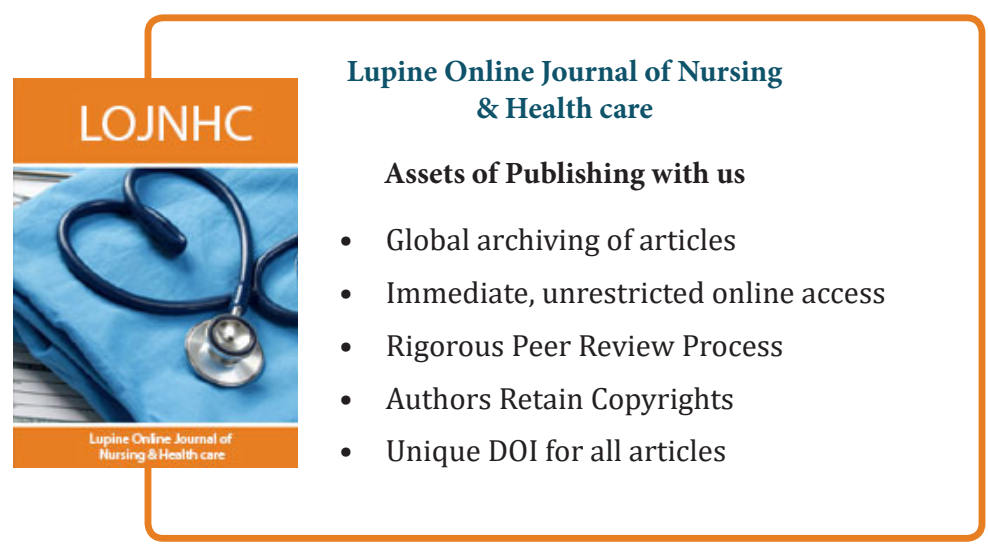

